\title{
Impact of the Covid-19 Pandemic on Severe Childhood Malaria at the University Hospital of Brazzaville
}

\author{
Moyen Engoba ${ }^{12^{*}}$, Arquevia Nature Ofamalekou Gnakingue ${ }^{1}$, Ben Borgea Nianga ${ }^{3}$, \\ Carel Ervane Goma ${ }^{1}$, Armel Landry Batchi-Bouyou${ }^{1}$, Annie Rachelle Okoko1,2, \\ Georges Marius Moyen"1,2 \\ ${ }^{1}$ Faculty of Health Sciences, Marien Ngouabi University, Brazzaville, Congo \\ ${ }^{2}$ Pediatric Intensive Care Service, University Hospital of Brazzaville, Brazzaville, Congo \\ ${ }^{3}$ Program and Project Coordination Unit, Ministry of Health and Population, Brazzaville, Congo \\ Email: *engoba_m@yahoo.fr
}

How to cite this paper: Engoba, M., Gnakingue, A.N.O., Nianga, B.B., Goma, C.E., Batchi-Bouyou, A.L., Okoko, A.R. and Moyen, G.M. (2021) Impact of the Covid-19 Pandemic on Severe Childhood Malaria at the University Hospital of Brazzaville. Open Journal of Pediatrics, 11, 301-312.

https://doi.org/10.4236/ojped.2021.112028

Received: April 28, 2021

Accepted: June 21, 2021

Published: June 24, 2021

Copyright $\odot 2021$ by author(s) and Scientific Research Publishing Inc. This work is licensed under the Creative Commons Attribution International License (CC BY 4.0).

http://creativecommons.org/licenses/by/4.0/

\begin{abstract}
Introduction: Malaria management has been a source of concern for health systems since the advent of the Covid-19 pandemic. Objective: To assess the impact of the Covid-19 pandemic on severe childhood malaria in Brazzaville. Material and Method: A quasi-experimental intervention/non-intervention study was carried out between March and October 2020 in the pediatric departments of the Brazzaville University Hospital. Children aged three months to 15 years hospitalized were the target population. Two groups were formed: the "intervention" group, that of children hospitalized between March and October 2020 and the "control" group that of those hospitalized between January and August 2015. The study variables were epidemiological, clinical, biological and therapeutic. Chi-square and T-Student tests were used. The impact of the intervention was assessed by the absolute risk difference. Results: Of 1392 children hospitalized, 199 (14.6\%) had severe malaria with an average age of 6.94 years. These were children under 5 years old $n=95$ (47.7\%) of low socioeconomic level $\mathrm{n}=145$ (72.9\%) seen on average after 4.6 +/- 2.4 days. Repeated convulsions (56.8\%) and anemia (20.1\%) were the main reasons for hospitalization. These were isolated forms $(\mathrm{n}=146 ; 73.4 \%)$ of which $n=84(42.2 \%)$ neurological and $n=62(31.2 \%)$ anemic. The lethality was $13.1 \%$. Delayed consultation, fever, repeated convulsions, pallor, respiratory distress, sickle cell anemia, thrombocytopenia and hypoglycemia are associated with death. The risk difference for signs of severity between the two periods was 16.6 for repeated convulsions; 14.3 for severe anemia. The relative risk between the two studies was 1.8. Conclusion: The increase in
\end{abstract}


morbidity and mortality in severe malaria since the beginning of the Covid-19 pandemic encourages the maintenance of the balance between the management of the Covid-19 pandemic and that of other worrying health problems.

\section{Keywords}

Impact, Covid-19, Severe Malaria, Children, Brazzaville

\section{Introduction}

Malaria, a major public health problem [1], is an endemic for which many resolutions have been taken: that of Abuja: "to roll back malaria" [2], the United Nations Millennium Declaration (UN): building together a more secure, prosperous and equitable world [3], the Millennium Development Goals (MDGs) [3] and the Sustainable Development Goals for the eradication of malaria in many countries by 2030. In 2019, 229 million cases of malaria were recorded worldwide, including 213 million in Africa. There were 409,000 deaths and, children under five were the most affected [4]. The severe forms are the fifth leading cause of death from infectious diseases in the world and second in Africa [5]. The high prevalence and relative mortality are variable: $18 \%-67.8 \%$ in the Democratic Republic of Congo (DRC) [6], 21.7\% in Senegal [7], 55.8\% in Mali [8] and $53 \%$ in Niger [9] with respectively $4 \%, 24 \%, 10 \%$, and $3.6 \%$ of deaths.

In Congo, the prevalence of severe forms of malaria was $11.2 \%$ in 2016 and mortality $6.5 \%$ [10]. While African populations continue to pay the heavy price for severe malaria [5], the Covid-19 pandemic risks are hampering the efforts of health systems around the world [11]. Our study aimed to assess the impact of the covid-19 pandemic on severe childhood malaria at the University Hospital of Brazzaville and the objectives: determine the frequency of severe malaria; describe the clinical, para-clinical, therapeutic and evolutionary aspects; identify the factors associated with the death of a child hospitalized for severe malaria during the Covid-19 pandemic period and report the indicators of its impact on severe childhood malaria in Brazzaville.

\section{Materials and Methods}

We carried out a quasi-experimental intervention/non-intervention study between March and October 2020, i.e. in eight months. Three of the four pediatric departments of the University Hospital of Brazzaville: grandchildren pediatrics, infant pediatrics and that of Pediatric Intensive Care (ICU) formed the framework of the study. The target population, made up of children aged three months to 15 years hospitalized in the aforementioned services was divided into two groups: group 1 or "intervention", that of children hospitalized between March and October 2020 and group 2 or "control". That of children hospitalized be- 
tween January and August 2015, eight months [10].

Children aged three months to 15 years hospitalized in the aforementioned services whose discharge diagnosis included, among other things, the item "severe malaria" [12] were included. Severe malaria was defined by the World Health Organization criteria [13]. This was a simple and consecutive probability sampling taking into account medical records and service registers. The sample size of group 2 "control" was that of the study carried out in the same wards in children admitted for "severe malaria" [10]. That of group 1 "intervention" was calculated from the SCHWARTZ formula. The minimum sample size was set at 153 patients.

The sample size of group 1 "control" corresponded to that of the studycarried out in the same services by Okoko [10], on "severe malaria" in children at the Brazzaville UniversityHospital: 382 patients. For group 2 “intervention" the sample size wascalculatedfrom the formula of Daniel Schwartz taking intoaccount a previousstudy by Okoko [10].

$$
\mathrm{N}=\mathrm{P}(1-\mathrm{P}) \cdot(\mathrm{Z} \alpha)^{2} / \mathrm{d}^{2}
$$

P: Expected proportion of subjectspresenting the studied variable (severe malaria in our case);

$\mathrm{Za}$ : Standardizedsignificancelevel = 1.96;

$\mathrm{d}^{2}$ : Imprecisiondeviation $=0.05$.

Severe malaria represented $11.2 \%$ of all children hospitalized during this studyperiod. Thus, $\mathrm{N}=0.112(1-0.112)(1.96) 2 /(0.05) 2=152.83 \mathrm{~N} \approx 153$ is the minimum size of the sampleallowing a statisticalanalysis.

The study variables were twofold. Those relating to the child: the mode and reason for admission, the consultation time, the antecedents, the functional and examination signs, the thick gout hematozoicsmear, the rapid diagnostic test (RDT), the Complete blood count (CBC), blood sugar, creatinemia, diagnosis, treatment and pattern. Those relating to parents: age, sex, marital status, socio-economic and cultural level and occupation.

The data were collected using a pre-established survey form developed and completed for this purpose. The antimalarials used were: artesunate $2.4 \mathrm{mg} / \mathrm{kg}$ for a weight greater than $20 \mathrm{~kg}$ and $3 \mathrm{mg} / \mathrm{kg}$ when it was less than $20 \mathrm{~kg}$ intravenous (IV) or intramuscular (IM) at H0, H12, H24 then a taken per 24 hours from day 2 to day 5; quinine base $20 \mathrm{mg} / \mathrm{kg}$ as a loading dose, then $10 \mathrm{mg} / \mathrm{kg}$ every eight hours. A relay by the oral route was authorized when the clinical state was considered stable. In this case, the artemether-lumefantrine combination was used after at least three days of parenteral treatment. The maximum duration of treatment was seven days. The other therapeutic means consisted of administration of $10 \%$ hypertonic glucose serum $50 \mathrm{~mL} / \mathrm{kg}$, diazepam $0.5 \mathrm{mg} / \mathrm{kg}$ intra-rectally, phenobarbital 10 to $15 \mathrm{mg} / \mathrm{kg}$ IV, hypertonic glucose serum $50 \% 1$ $\mathrm{mL} / \mathrm{kg}$, the erythrocyte pellet using Molison's formula (amount $=3 \times$ weight [desired $\mathrm{Hb}$-diseased $\mathrm{Hb}$ ]) and furosemide $1-2 \mathrm{mg} / \mathrm{kg}$.

In all cases, the criteria for cure were the achievement of apyrexia and the 
denial of thick gout. The other criteria, depending on the clinical form were the recovery of consciousness, the re-coloring of the mucous membranes, the integuments and the appearance of the urine, the resumption of food and walking, a hemoglobin level within the limits of normal and normalization of renal function.

\subsection{Data Analysis}

The software Epi info version 7.2 and Stata 13 were used for data processing. Chi-square and T-Student tests for the comparison of proportions and means. The significance level was set $p$ less than or equal to $5 \%$ and the confidence interval at $95 \%$. The impact of the intervention was assessed by the absolute risk difference (DR).

\subsection{Ethical Considerations}

To carry out this work, approval from the Scientific Research Ethics Committee (CERSSA) in Congo as well as a research authorization issued by the Faculty of Health Sciences of Marien Ngouabi University were obtained.

\section{Results}

\subsection{Descriptive Study}

\subsubsection{Frequency and Socio-Demographic Characteristics of the Study Population}

Out of 1392 children hospitalized in the pediatric departments of the University Hospital of Brazzaville, 199 (14.3\%) were hospitalized for severe malaria, of which $64.3 \%(\mathrm{n}=128)$ in pediatric intensive care, $14.6 \%(\mathrm{n}=29)$ in infant pediatrics and $21.1 \%(\mathrm{n}=42)$ in older children pediatrics. These were 110 boys (55.3\%) and 89 girls (44.7\%): sex ratio 1.2. The average age was $6.94 \pm 4.81$ years, extremes ( 3 months and 15 years): Table 1 . They resided in Brazzaville $\mathrm{n}=192$ (96.5\%) and in another locality of Congo $\mathrm{n}=7(3.5 \%)$. They came from home without prior recourse to a health center $\mathrm{n}=107$ (53.8\%); referred from a basic hospital $n=58(31.1 \%)$, an integrated health center $n=11(5.5 \%)$ and a doctor's office $n=19$ (9.6\%).

Table 1. Distribution of children by age group and sex.

\begin{tabular}{|c|c|c|c|c|c|c|}
\hline \multirow{3}{*}{ Age (years) } & \multicolumn{4}{|c|}{ Sex } & \multirow{2}{*}{\multicolumn{2}{|c|}{ Total }} \\
\hline & \multicolumn{2}{|c|}{ Male } & \multicolumn{2}{|c|}{ Female } & & \\
\hline & $\mathbf{n}$ & $\%$ & $\mathbf{n}$ & $\%$ & $\mathrm{n}$ & $\%$ \\
\hline $0-5$ & 48 & 43.6 & 47 & 52.8 & 95 & 47.7 \\
\hline $6-11$ & 34 & 30.9 & 26 & 29.2 & 60 & 30.2 \\
\hline \multirow[t]{2}{*}{$12-15$} & 28 & 25.5 & 16 & 18.0 & 44 & 22.1 \\
\hline & 110 & 100 & 89 & 100 & 199 & 100 \\
\hline
\end{tabular}


The parents were between 17 and 20 years old $n=17(8.5 \%)$ for the mothers and none for the fathers, 20 and 29 years old $n=50(25.1 \%)$ for the mothers versus 38 (19.7\%) for fathers, 30 and 39 years old $n=81(40.7 \%)$ for mothers versus $82(41.2 \%)$ for fathers and over 40 years $n=53$ (26.6\%) for mothers versus $\mathrm{n}=79$ (39.7\%). They had an average age of $31.14 \pm 7.91$ years extreme (17 and 53 years) for the mothers versus $37.38 \pm 8.22$ years, extreme (20 and 63 years) for the fathers. The level of education was that of primary $\mathrm{n}=34$ (17.15\%) for mothers versus $\mathrm{n}=40(20.1 \%)$ for fathers, secondary $\mathrm{n}=145$ (72.9\%) for mothers versus $\mathrm{n}=98(49.3 \%)$ for fathers, academic $\mathrm{n}=19(9.5 \%)$ for mothers versus $n=54$ (27.1\%). Seven (3.5\%) fathers and one mother were not in school.

The parents were without profession $75(37.7 \%)$ mothers versus $21(10.5 \%)$ fathers. They worked in the informal sector 65 (32.7\%) mothers versus 42 (21.1\%) fathers. They were manual workers $44(22.1 \%)$ mothers versus $100(50.3 \%)$ fathers and executives 15 (7.5\%) mothers versus 36 (18.1\%) fathers. The socioeconomic level was low $\mathrm{n}=145(72.86 \%)$, medium $\mathrm{n}=49(24.6 \%)$ and high $\mathrm{n}=5$ $(2.5 \%)$. They lived as a couple $\mathrm{n}=145(73.9 \%)$ and were separated $\mathrm{n}=52$ (26.1\%).

\subsubsection{Clinical Aspects}

The mean time to consultation was $4.6 \pm 2.4$ extreme days (one and 25 days). It was less than two days $n=9(4.5 \%)$; between two and five days $n=128$ (64.3\%); greater than five days $\mathrm{n}=62(31.2 \%)$. Before hospitalization, antimalarial treatment was administered $\mathrm{n}=121(60.8 \%)$ including: quinine $\mathrm{n}=33(27.3 \%)$, artemisinin $\mathrm{n}=69(57.0 \%)$ and artesunate $\mathrm{n}=19$ (15.7\%). Medicines were obtained over the counter $n=66(33.2 \%)$, on prescription from paramedical staff $n$ $=27(13.6 \%)$, from a general practitioner $\mathrm{n}=58(29.1 \%)$ and from a pediatrician $\mathrm{n}=6(3.0 \%)$.

The symptoms that formed the reason for consultation, associated or not in the same patient were: a repeated convulsion $n=113(56.8 \%)$, anemia $n=40$ (20.1\%), a fever $\mathrm{n}=36(18.1 \%)$ and disturbance of consciousness $\mathrm{n}=52(26 \%)$ and coma $\mathrm{n}=14(7.0 \%)$.

The examination signs were: fever $\mathrm{n}=151(76 \%)$, pallor $\mathrm{n}=160(80.4 \%)$, coma $\mathrm{n}=85$ (42.7\%); agitation (disturbance of consciousness) $\mathrm{n}=12(6.0 \%)$, splenomegaly $n=58(28.1 \%)$, hepatomegaly $n=5(2.5 \%)$, respiratory distress $n$ $=5(2.5 \%)$.

Nineteen children (9.5\%) were dehydrated and 29 (14.6\%) presented a nutritional disorder made up of moderate undernutrition $n=24(12.1 \%)$ and overweight $\mathrm{n}=5(2.5 \%)$.

\subsubsection{Biological Parameters}

The parasite density was on average 10,947.64 \pm 2057.44 extreme parasites $/ \mu \mathrm{L}$ (36 and 19,000 P/ $\mu \mathrm{L}$ of blood) and less than 100,000 in all cases. The mean hemoglobin level was $5.2 \pm 3.0 \mathrm{~g} / \mathrm{dl}$, range (2.3 and 7.5); platelets less than 
$100,000 / \mathrm{mm}^{3}$ in $62(31.2 \%)$ cases with a mean of extreme $185,407.15 \pm 2.96 / \mathrm{mm}^{3}$ $\left(88,000\right.$ and $\left.826,000 / \mathrm{mm}^{3}\right)$. The mean blood sugar level was $0.84 \pm 0.3 \mathrm{~g} / \mathrm{l} \mathrm{ex}-$ tremes $(0.32$ and $1.20 \mathrm{~g} / \mathrm{l})$ and less than $0.4 \mathrm{~g} / \mathrm{l}$ in $17(8.5 \%)$ cases. The mean serum creatinine level was extreme $12.27 \pm 6.3 \mu \mathrm{mol} / \mathrm{l}(0.72$ and $15.38 \mu \mathrm{mol} / \mathrm{l})$ and elevated in 4 children $(2.7 \%)$.

\subsubsection{Clinical Forms}

It was an isolated form 146 (73.4\%) of which 84 (42.2\%) neurological form and $62(31.2 \%)$ anemic. There were $53(26.6 \%)$ cases of associated forms. The associations were: anemic and neurologic 28 (14.1\%) cases; anemic, neurological and hypoglycemia $8(4.0 \%)$ cases, anemic, neurological and jaundice $8(4.0 \%)$ cases; neurological anemia, hypoglycemia and jaundice $5(2.5 \%)$ cases; anemic, neurological, hypoglycemia, jaundice and renal failure $4(2.0 \%)$ cases.

Severe malaria was associated with pneumonia $\mathrm{n}=11(5.5 \%)$, tuberculosis $\mathrm{n}=$ $5(2.5 \%)$, HIV infection $n=4(2.0 \%)$ and meningitis $n=2(1.0 \%)$. This was a child living with sickle cell disease $n=13(6.5 \%)$.

\subsection{Treatment}

Specific treatment consisted of the administration of artesunate $\mathrm{n}=193(97.0 \%)$ and quinine $\mathrm{n}=6(3.0 \%)$. The other drugs administered were: an anticonvulsant including diazepam $n=104(52.3 \%)$ and phenobarbital $n=93(46.7 \%)$; erythrocyte pellet $n=140(94.6 \%)$, fresh frozen plasma and whole blood $n=4(2.7 \%)$ cases each.

\subsubsection{Evolution}

The outcome was favorable: 167 (83.9\%) cases, and one death noted in $26(13.1 \%)$ cases, involving children aged 0 to 514 (14.7\%) cases, aged 6 and $115(8.3 \%)$ cases and from 12 to 15 years $7(16.0 \%)$ cases. They were divided into $15(57.7 \%)$ boys and $11(42.3 \%)$ girls.

The mean length of hospital stay was $2 \pm 1.5$ extreme days ( 1 and 7 days) in the fatalities and $3 \pm 3.5$ extreme days ( 1 and 4 days) in the living.

\subsubsection{Analytical Study}

The delay in the consultation, beyond two days; the reason for consultation is anemia; repeated convulsions, examination signs including pallor, fever, respiratory distress; association with sickle cell anemia, sickle cell anemia; thrombocytopenia, hypoglycemia and length of hospital stay predicted death (Table 2).

\subsubsection{Comparative Analysis}

The comparative elements between the control study and the control study on the elements of severity of severe malaria according to WHO are given in Table 3 and Table 4. Morbidity from severe malaria increased from $11.2 \%$ with a mortality of $6.2 \%$ in the control study in 2016 and in our study these figures are clearly increasing with a morbidity of $14.3 \%$ and a mortality of $13.1 \%$. 
Table 2. Predictors of death.

\begin{tabular}{|c|c|c|c|c|c|c|c|c|}
\hline \multirow{3}{*}{ Time (days) } & \multirow{3}{*}{$\begin{array}{c}\text { Total } \\
n\end{array}$} & \multicolumn{6}{|c|}{ Death } & \multirow{3}{*}{ p-value } \\
\hline & & \multicolumn{2}{|c|}{ Yes } & \multicolumn{2}{|c|}{ No } & \multirow{2}{*}{ Chi-2 } & \multirow{2}{*}{ OR (IC à 95\%) } & \\
\hline & & $\mathrm{n}$ & $\%$ & $\mathrm{n}$ & $\%$ & & & \\
\hline \multicolumn{9}{|l|}{ Time to consultation } \\
\hline$<2$ & 9 & 2 & 7.6 & 7 & 4.1 & 0.6 & $1.9[0.3-10.1]$ & 0.4 \\
\hline $2-5$ & 128 & 10 & 38.46 & 118 & 68.21 & 5.7 & $3.4[1.4-8.0]$ & 0.003 \\
\hline$>5$ & 62 & 14 & 53.8 & 48 & 27.8 & 60.9 & $3.0[1.3-7.0]$ & 0.007 \\
\hline \multicolumn{9}{|l|}{ Reason for consultation } \\
\hline Repeated convulsions & 113 & 5 & 19.2 & 108 & 47.2 & 7.3 & $3.7[1.3-10.2]$ & 0.006 \\
\hline Anemia & 40 & 11 & 42.3 & 29 & 12.6 & 11.5 & $5.0[2.1-12.0]$ & 0.0008 \\
\hline Fever & 36 & 7 & 26.9 & 29 & 12.6 & 3.9 & $2.5[0.9-6.7]$ & 0.05 \\
\hline Conscience disorder & 52 & 2 & 7.7 & 50 & 21.8 & 2.8 & $3.3[0.7-14.6]$ & 0.08 \\
\hline Coma & 14 & 1 & 3.85 & 13 & 5.7 & 0.2 & $1.5[0.1-11.9]$ & 0.6 \\
\hline \multicolumn{9}{|l|}{ Clinical symptoms } \\
\hline Fever & 151 & 15 & 57.7 & 136 & 30.2 & 6.5 & $3.1[1.4-7.0]$ & 0.003 \\
\hline Pallor & 160 & 4 & 15.4 & 12 & 2.7 & 12.2 & $6.6[1.9-22.2]$ & 0.004 \\
\hline Splenomegaly & 58 & 1 & 3.9 & 7 & 1.6 & 0.7 & $2.5[0.2-21.3]$ & 0.3 \\
\hline Coma & 85 & 2 & 7.7 & 83 & 18.4 & 1.9 & $2.7[0.6-11.7]$ & 0.16 \\
\hline Hepatomegaly & 5 & 1 & 3.85 & 4 & 0.9 & 2.0 & $4.4[0.4-41.3]$ & 0.15 \\
\hline Trouble de la conscience & 12 & 1 & 3.85 & 11 & 2.44 & 0.19 & $1.5[0.1-12.8]$ & 0.65 \\
\hline Respiratory distress & 5 & 2 & 7.7 & 3 & 1.7 & 11.6 & $12.4[1.9-77.8]$ & 0.0006 \\
\hline \multicolumn{9}{|l|}{ Associated pathologies } \\
\hline Pneumonia & 11 & 1 & 3.9 & 10 & 5.6 & 0.16 & $1.5[0.1-12.5]$ & 0.6 \\
\hline Tuberculosis & 5 & 0 & 0 & 5 & 2.9 & - & - & - \\
\hline infection à VIH & 4 & 1 & 3.9 & 3 & 1.7 & 2.2 & $0.5[0.2-22.6]$ & 0.4 \\
\hline Meningitis & 2 & 1 & 3.9 & 1 & 0.6 & 2.4 & $0.1[0.4-11.0]$ & 0.11 \\
\hline Sickle cell disease & 13 & 6 & 24.0 & 7 & 4.1 & 14.1 & $7.4[2.2-24.5]$ & 0.0001 \\
\hline \multicolumn{9}{|l|}{ Duration of hospitalization } \\
\hline $1-3$ & 122 & 24 & 92.3 & 98 & 56.6 & 12.1 & 1 & 0.0004 \\
\hline$>3$ & 77 & 2 & 7.7 & 75 & 43.4 & & $9.1[2.1-40.0]$ & \\
\hline \multicolumn{9}{|l|}{ Thrombopenia } \\
\hline$<100,000$ & 62 & 12 & 46.1 & 50 & 28.9 & 3.1 & $2.1[0.9-4.8]$ & 0.07 \\
\hline$>100,000$ & 137 & 14 & 53.9 & 123 & 71.1 & & 1 & \\
\hline \multicolumn{9}{|l|}{ Hypoglycemia } \\
\hline$<4 \mathrm{mg} / \mathrm{l}$ & 17 & 6 & 23.1 & 11 & 6.4 & 8.0 & $4.4[1.4-13.2]$ & 0.004 \\
\hline$>4 \mathrm{mg} / \mathrm{l}$ & 182 & 20 & 76.9 & 162 & 93.6 & & 1 & \\
\hline
\end{tabular}


Table 3. Comparative elements of the severity criteria of the control study versus our study.

\begin{tabular}{|c|c|c|c|c|c|c|c|c|}
\hline & \multicolumn{4}{|c|}{ Source } & & & & \\
\hline & \multicolumn{2}{|c|}{ Our study } & \multicolumn{2}{|c|}{ Death } & \multicolumn{2}{|c|}{ Okoko study } & \multicolumn{2}{|c|}{ Death } \\
\hline & Total & Frequency & $\mathrm{n}$ & $\%$ & Total & Frequency & $\mathrm{n}$ & $\%$ \\
\hline Study framework & \multicolumn{2}{|c|}{ Brazzaville-Congo } & & & \multicolumn{2}{|c|}{ Brazzaville-Congo } & & \\
\hline Type of study & \multicolumn{2}{|c|}{ Descriptive quasi-experimental } & & & \multicolumn{2}{|c|}{ Prospective study } & & \\
\hline Study period & \multicolumn{2}{|c|}{ March-October 2020} & & & \multicolumn{2}{|c|}{ January-august 2015} & & \\
\hline Total & 199 & 14.3 & & & 382 & 6.2 & & \\
\hline Children < 5 years $(\%)$ & 95 & 47.7 & & & 174 & 45.5 & & \\
\hline \multicolumn{9}{|l|}{ Severity criteria } \\
\hline Neurologcal & 118 & 59.3 & & & 229 & 18.3 & 14 & 11.9 \\
\hline Conscience disorder & 52 & 1.50 & - & - & 59 & 15.4 & 5 & 7.8 \\
\hline Repeated convusions & 113 & 54.2 & 5 & 19.2 & 104 & 27.2 & 14 & 11.9 \\
\hline Prostration & - & - & - & - & 66 & 17,2 & 0 & \\
\hline Coma & 85 & 3.5 & 3 & 11.6 & 70 & 18.3 & - & - \\
\hline Anemia & 40 & 14.6 & 11 & 42.3 & 223 & 61.5 & 12 & 5.1 \\
\hline Respiratory distress & 3 & - & 2 & - & 33 & 8.6 & 13 & 28.3 \\
\hline Jaundice & - & - & - & - & 18 & 4.7 & 3 & 14.3 \\
\hline Hemoglobinuria & - & - & - & - & 64 & 17.5 & 3 & 4.5 \\
\hline Hypoglycemia & 17 & 8.5 & 6 & 23.1 & 19 & 4.9 & 8 & 29.6 \\
\hline Renal failure & 3 & 1.5 & 1 & 3.8 & 7 & 1.8 & 1 & 12.5 \\
\hline Dehydration & 19 & 9.5 & 0 & - & 17 & 4.4 & - & - \\
\hline
\end{tabular}

Table 4. Comparative study of the difference in risk of signs of severity.

\begin{tabular}{cccc}
\hline Signs & Groupe 1 Intervention & Groupe 2 Control & $\begin{array}{c}\text { Risk difference in } \\
\text { absolute value }\end{array}$ \\
\cline { 2 - 4 } & OR IC (95\%) & OR IC (95\%) & 0.1 \\
\hline Repeated convulsions & $3.7[1.3-10.2]$ & $3.1[1.4-7]$ & - \\
Dehydration & - & $2.7[0.6-11]$ & 1.7 \\
Fever & $2.5[0.9-6.7]$ & $0.9[0.3-3.1]$ & 0.8 \\
Coma & $2.7[0.6-11.7]$ & $13[5-33.7]$ & 1.5 \\
Splenomegaly & $2.5[0.2-21.3]$ & $1[0.4-2.6]$ & 7.3 \\
Severe anemia & $5.0[2.1-12.0]$ & $0.6[0.2-2.1]$ & - \\
Jaundice & - & $2.6[0.7-9.4]$ & 0.5 \\
Hypoglycemia & $4.4[1.4-13.2]$ & $8.4[3.2-21.8]$ & 0.04 \\
Renal faillure & $2.2[0.2-22.6]$ & $2.1[0.2-17.6]$ & \\
\hline
\end{tabular}




\subsubsection{Difference in Risk of Signs of Severity between the Two Groups}

The risk difference is 0.1 for seizures; 1.7 for fever; 0.8 for coma; 1.5 for splenomegaly; 7.3 for anemia; 0.5 for hypoglycemia and 0.04 for renal failure. It follows that the percentage of subjects to be treated to prevent death from severe malaria during a Covid-19 pandemic is $100 \%$ for coma, convulsions and hypoglycemia; $66.6 \%$ for splenomegaly; $58.8 \%$ for fever and $13.7 \%$ for anemia.

Children under 15 have a relative risk of death from severe malaria 1.8 times higher during Covid-19 compared to those in the control study.

\section{Discussion}

As Covid-19 continues to occupy the political health agenda in many countries around the world, so does its impact on certain diseases which is becoming apparent. Malaria is one of them. The general objective of this study was: to assess the impact of the Covid-19 pandemic on severe childhood malaria in Brazzaville and specifically: to determine its frequency, to describe the nosological varieties, to assess the evolutionary profile, to identify the factors associated with deaths during the period of the Covid-19 pandemic and report the indicators of the impact of the Covid-19 pandemic on severe malaria in children hospitalized at the Brazzaville CHU by referring to a previous study [10] of which the methodology was identical to ours. The high mortality, attributable to severe malaria despite the efforts made for its reduction by the international community guided our choice, which was reinforced by the cry of alarm from the WHO which feared that the Covid-19 pandemic would be wiped out. The benefits obtained over the last twenty years by the health systems of the various countries [11]. To achieve our objectives, a cross-sectional study carried out in the largest hospital in Brazzaville seemed to us the ideal setting. However, the conduct of the study was a source of bias, including those relating to its implementation during the period of the health emergency coupled with the confinement of the population. This study presents in its implementation somelimitations, relating to its duration, namely eight months, its implementation during a period of confinement, state of health emergency, source of recruitment bias.

\subsection{Epidemiological Aspects}

This work confirms the severity of severe malaria, the role of which in child mortality in developing countries is well known [14] [15] [16]. In the Congo, the relative mortality, which has fallen sharply, from $26.3 \%$ in 2010 [17] to $6.5 \%$ in 2016 [10], has increased: 13.2\%. Children of average age: 6.9 years old, more under the age of five (47.7\%) are, as everywhere in Africa, the most affected [6] [18] [19]. A common denominator of deaths related to severe malaria is delayed consultation [15] [16] [18], which is correlated with risk of death [10] [17]. Lack of awareness of signs of seriousness, inadequate management of simple forms, the low socio-cultural and economic level of the populations are associated with the delay in consultation and the constraints linked to the Covid-19 pandemic. 


\subsection{Clinical and Therapeutic Aspects}

Clinically, the most commonly observed severity criteria known [10] [15] [16] [20] [21] are anemia, convulsions, coma, thrombocytopenia and hypoglycemia. As already reported, the neurological and anemic forms are predominant [6] [10] [22] [23] [24]. And that the association of severe malaria with sickle cell disease increases the risk of death.

\subsection{Evolution and Risk Factors for Death}

The progression to death observed in $13.1 \%$ of the children in this study and $6.5 \%$ in the control study [10] is in both cases more attributable to anemic and neurological forms but also to hypoglycemia and at thrombocytopenia. The predictive factors of death, which vary from one study to another, are: delayed consultation, fever, repeated convulsions, pallor, respiratory distress, sickle cell anemia, thrombocytopenia and hypoglycemia.

\subsection{Influence of the Covid-19 Period on the Management of Severe Malaria}

In March 2020, WHO underlined the value of maintaining activities for the prevention, diagnosis and treatment of malaria, key to the strategy to reduce the pressure on health systems when an additional burden is expected due to the Covid-19. These forecasts related to the disruptions observed in the supply chain of essential tools for the fight against malaria due to containment measures and the priority given to imports and exports of materials intended for the fight against Covid-19. In the context of a deficit of activities related to the fight against malaria, WHO estimated that "the number of deaths due to malaria in sub-Saharan Africa in 2020 would reach 769,000, a number twice as high as in 2018. This which would represent a return to the level of mortality observed for the last time in 2000" [25]. This is the case for our study, which reports severe malaria morbidity of $14.6 \%$ and mortality of $13.1 \%$ versus $11.6 \%$ morbidity and $6.5 \%$ mortality for the control study and a risk relative death rate 1.8 times higher during the period of the Covid-19 pandemic, thus confirming the WHO forecasts [26].

\section{Conclusion}

The morbidity and mortality linked to severe childhood malaria have doubled in Brazzaville since the advent of the Covid-19 pandemic. The anemic and neurological forms are the most observed. Delayed consultation, fever, repeated convulsions, pallor, respiratory distress, sickle cell anemia, thrombocytopenia and hypoglycemia are associated with death. Mortality from severe malaria is twice as high during the Covid-19 pandemic. It seems imperative for health systems to ensure that a balance is maintained between the management of the Covid-19 pandemic and that of other worrying health problems, including malaria. 


\section{Conflicts of Interest}

The authors declare no conflicts of interest regarding the publication of this paper.

\section{References}

[1] WHO (World Health Organization) (2017) World Malaria Report. https://apps.who.int/iris/bitstream/handle/10665/259492/9789241565523-eng.pdf;js essionid=AE9C7FA6E5D1970EC3C5DD6DBA36EC24? ua $=1$ ? sequence $=1$

[2] WHO (World Health Organization) (2003) Déclarationd'Abuja et plan d'action. Faire reculer le paludisme/Organisation Mondiale de la Santé, No. 46, WHO/CDS/RBM/, 1-12

[3] OMS (Organisation Mondiale de la Santé) (2015) Objectifs du millénaire pour le développement. La santé dans le programmedéveloppement de l'ONU après 2015. https://www.who.int

[4] WHO (World Health Organization) (2019) World Malaria Report. https://apps.who.int/iris/bitstream/handle/10665/330011/9789241565721-eng.pdf

[5] Bobossi-Serengbe, G., Ndoyo, J., Mukeshimana, T., Fioboy, R.I. and Ayivi, B. (2006) Paludisme grave de l'enfant à l'hôpitalpréfectoral de Bouar (Centrafrique). Médecine d Afrique Noire, 53, 219-222.

[6] Kunuanunua, T.S., Nsibu, C.N., Bodi, J.M., Tshibola, T.K., Bura, M.M., Magoga, K., et al. (2015) Severe Malaria in Children: A Descriptive Report from Kinshasa, the Democratic Republic of Congo. Journal of tropical Pediatrics, 61, 272-278. https://doi.org/10.1093/tropej/fmv029

[7] Keita, Y., Sylla, A., Thiongane, A. and Sall, M.G. (2017) Prévalenceactuelle du paludisme chez les enfants fébriles au Sénégal. Archives de Pédiatrie, 24, 415-416. https://doi.org/10.1016/j.arcped.2017.01.002

[8] Maiga, B., Sacko, K., Cissouma, A., Dembélé, A., Cissé, M., Diakité, A.A., et al. (2019) Caractéristiques du paludisme grave chez les enfants de 0 à 5 ans à l'hôpital de SIKASSO au Mali. Mali Medical, 34, 1-5.

[9] Mansour, M.A., Samaila, B., Mahamane, M.L., Mahamadou, D., Ramatoulaye, H.L., Ibrahim, A., et al. (2019) Facteursassociés au paludisme grave de l'enfant et son pronostic à l'hôpital National de Niamey, Niger. Médecine d'Afrique Noire, 66, 466-476.

[10] Okoko, A.R., Angouma Oya, S.M., Moyen, E., Kambourou, J., Ekouya-Bowassa, G., Atanda, H.L. and Moyen, G. (2016) Paludisme grave de l'enfant au Centre Hospitalier et Universitaire de Brazzaville. Journal de pédiatrie et puériculture, 29, 304-309. https://doi.org/10.1016/j.jpp.2016.09.004

[11] Kangasong, J.N. and Mankoula, W. (2020) Manaceimmented'Infection au COVID 19 en Afrique. Agissezcollectivement et rapidement. Lancette, (publierenligne le 27 Février).

[12] Guedehoussou, T., Agbeko, F., Fiawoo, M., Amoussou, K., Dossou, F., Takassi, O.E., et al. (2017) Paludisme grave chez l'enfant à l'hôpitald'enfantsyendoube de dapaong au Togo. Journal de la Recherche Scientifique de l'Université de Lomé, 19. 589-593.

[13] WHO (World Health Organization) (2012) Management of Severe Malaria. World Health Organization, Geneva.

https://apps.who.int/iris/bitstream/handle/10665/79317/9789241548526_eng.pdf;jse $\underline{\text { ssionid }=8668332728 \mathrm{~A} 3174 \mathrm{BCC} 6 \mathrm{BC} 0149456 \mathrm{D} 785 \text { ? } \text { sequence }=1}$ 
[14] Asse, K.V., Brou, Y. and Plo, K.J. (2003) Paludisme grave de l'enfant au CHU de BouakéenRépubliquede Côte d'Ivoire. Archives de Pédiatrie, 10, 62. https://doi.org/10.1016/S0929-693X(03)00226-4

[15] Mushagalusa, B., Babunga, M., Badibanga, M., Karazo, N., Riziki, M. and Kibibi, K. (2013) Cerebral Malaria in Children in LWIRO (South Kivu DRC). International Journal of Innovation and Applied Studies, 13, 178-184.

[16] Koueta, F., Dao, L., Zoungrana, A., Kabore, A. and Sawadogo, A. (2007) Facteurs de risque des décès au cours du paludisme grave au centrehospitalieruniversitairepédiatrique Charles de Gaulle d'Ouagadougou (Burkina Faso). Cahier de Santé, 17, 195-199.

[17] Moyen, G., Mbika-Cardorelle, A., Kambourou, J., Oko, A. and Mouko, A. (2010) Paludisme grave de l'enfant. Médecine d Afrique Noire, 57, 113-116.

[18] Ossou-Nguiet, P.M., Okoko, A.R., Ekouya Bowassa, G., Oko, A.P., Mabiala-Babela, J.R., Ndjobo Mamadou, I.C. and Moyen, G. (2013) Déterminants du neuropaludismeen milieu pédiatriquecongolais. Revue Neurologique, 169, 510-514. https://doi.org/10.1016/j.neurol.2012.11.003

[19] Dzeing-Ella, A., Nze Obiang, P.C., Tchoua, R., Planche, T., Mboza, B., Mbounja, M., et al. (2005) Severe Falciparum Malaria in Gabonese Children: Clinical and Laboratory Feature. Malaria Journal, 4, Article No. 1. https://doi.org/10.1186/1475-2875-4-1

[20] Ajetunmobi, W.A., Orimadegun, A.E., Brow, B.J., Afolabi, N.K., Olabiyi, F.A., Anetor, J.I., et al. (2012) Haemoglobinuria among Children with Severe Malaria Attending Tertiary Care in Ibadan, Nigeria. Malaria Journal, 11, Article No. 336. https://doi.org/10.1186/1475-2875-11-336

[21] Kunuanunua, T.S., Nsibu, N.C., Gini-Ehungu, J.L., Bodi, J.M., Ekulu, P.M., Situakibanza, H., et al. (2013) Insuffisancerénaleaigue dans les formes graves du paludisme chez les enfants vivants à Kinshasa. Néphrologie \& Thérapeutique, 9, 160-165. https://doi.org/10.1016/j.nephro.2013.01.001

[22] Jollow, M., Casals-Pascual, C., Ackerman, H., Walther, B., Walther, M., Pinder, M., et al. (2012) Clinical Faeatures of Severe Malarie Associated with Desth: A 13-Year Observational Study in the Gambia. PLoS ONE, 7, e45645.

https://doi.org/10.1371/journal.pone.0045645

[23] Imbert, P. and Banerjee, A. (2002) Paludisme de l'enfant. EMC, Pédiatrie, 4-320-A-20, Maladies Infectieuses, 8-507-A-30, $24 \mathrm{p}$.

[24] Tchokoteu, P.F., Bitchong-Ekono, C., Tietche, F., Tapko, J.B., Same Ekobo, A., Douala-Mouteng, V., et al. (1999) Severe Forms of Malaria in Children in a General Hospital Pediatric Department in Yaounde, Cameroon. Bulletin de la Societe de Pathologie Exotique, 92, 153-156.

[25] Chiodini, J. (2020) COVID-19 and the Impact on Malaria. Travel Medicine and Infectious Disease, 35, Article ID: 101758. https://doi.org/10.1016/j.tmaid.2020.101758

[26] OMS (Organisation Mondiale de la Santé) (2020) L'OMS appelle à relancer la lutte contre le paludisme.

https://www.who.int/fr/news/item/30-11-2020-who-calls-for-reinvigorated-action-t o-fight-malaria 